\title{
Agronomic Performance and Hydrocyanic Acid Potential (HCN-p) of Single and Three-Way Sorghum-Forage Hybrids and DeKalb Hybrid SX-17 1
}

\author{
S. Torres-Cardona, A. Sotomayor-Rios, and L. Telek ${ }^{2}$
}

\section{ABSTRACT}

\begin{abstract}
Eleven sorghum forage entries, including five single crosses, five threeway hybrids and DeKalb hybrid SX-17 were evaluated for yield of green forage (GF), yield of dry forage (DF), crude protein (CP) content, CP yield, height, leaf area, number of tillers, leaf-stem ratio and hydrocyanic acid potential $(\mathrm{HCN}-\mathrm{p})$ at Isabela, Puerto Rico. Four cuttings were made. The second harvest, 112 days after planting, had the highest DF yield, and the lowest CP content. When data for all harvests were combined, the single cross of AT $\times 624 \times$ Common sudangrass, three-way hybrid (AT $\times 624 \times$ BRhodesian) $\times$ Common sudangrass and single cross hybrid ARhodesian $\times$ Common sudangrass produced the highest DF yields. These were significantly higher than those of DeKalb hybrid SX-17. The highest DF yield was that from single cross hybrid AT $\times 624 \times$ Common sudangrass $(17,303 \mathrm{~kg} / \mathrm{ha}$ in 217 days), which exceeded by $11 \%$ and $13 \%$ the 2 nd and 3rd highest producers. Based on orthogonal comparisons, single crosses were on the average superior to three-way hybrids in yield and most of the other characteristics studied. Three-way hybrids had a lower average HCN content $(250 \mathrm{p} / \mathrm{m})$ than single crosses $(285$ $\mathrm{p} / \mathrm{m}$ ). These values are slightly higher than the $200 \mathrm{p} / \mathrm{m}$ level at which HCN toxicity may begin to affect animals. Results indicate that any of the three top hybrids of this study would be an excellent choice for farmers desiring high forage production under irrigation in Puerto Rico.
\end{abstract}

\section{INTRODUCTION}

Few reports are available in Puerto Rico concerning the use of forage sorghums, in spite of their great potential for production throughout the year. In studies conducted in the Lajas Valley, Vázquez et al. (18) reported dry forage yields of over 35 tons per hectare with "Millo Blanco" (MB), a local forage-sorghum variety. Sotomayor-Ríos and Telek (14) obtained dry forage yields of 17 tons per hectare from hybrid CK-60 $\times$ MB, with an average crude protein content of $17.6 \%$ during a 211 -day period at Isabela. On the basis of cuttings at a 30-day interval Sotomayor-Ríos and Santiago (16) reported dry forage yields of 20 tons per hectare in 140 days or $143 \mathrm{~kg} \cdot \mathrm{ha}^{-1} \cdot$ day $^{-1}$, with an average crude protein content of about 14.3\%. Morales (10) evaluated a series of hybrids of forage-sorghum and sorgo-sudan at Isabela, and reported yields of over 40 tons of dry forage/ha yearly when harvested at a 45 -day interval.

Although forage sorghums are excellent in terms of high forage yields

\footnotetext{
${ }^{1}$ Manuscript submitted to Editorial Board November 2, 1981.

${ }^{2}$ Agronomist; Research Geneticist; and Research Chemist, Mayagüez Institute of Tropical Agriculture, ARS/SEA/USDA, Mayagüez, P.R. 00709, respectively.
} 
over short life cycles, one of the objections to their use is the possibility of poisoning livestock with hydrocyanic (prussic) acid, which may be released during the digestive process from dhurrin present in the forage (4).

According to $\mathrm{McBee}$ and Miller (9) considerable genetic variation exists among sorghums in inherent levels of dhurrin or HCN-p. It has been found that $\mathrm{N}$ fertilization increases dhurrin levels (9) and that young regrowth is more likely to be toxic to animals than mature crops (4). Many other factors such as soil fertility, stress, genetic variation, age and location of tissue in the plant influence the level of HCN-p in sorghums $(2,4,6)$. Levels of HCN tend to increase when growth is slowed by injury and lack of water $(2,6)$.

The literature concerning the use of three-way sorghum hybrids, either for forage or grain purposes, is very limited $(11,12)$. As early as 1969, Ross (12) stated that three-way hybrids could have a definite yield advantage over single crosses, but since then no additional information has become available to verify this statement. The development of threeway hybrids involves an additional generation, a factor which needs to be evaluated in economic terms in comparing them to single crosses. If three-way forage hybrids prove capable of producing yields superior to those of single crosses over several consecutive harvests in the tropics, their development might well be justified.

The objectives of this study were to compare a series of agronomic traits of five single and five three-way crosses and DeKalb hybrid SX-17 sorghums and to determine whether differences exist among them in terms of their HCN-p after four consecutive harvests in the tropics.

\section{MATERIALS AND METHODS}

In the summer of 1978, hand crosses were made among 2 male sterile $(\mathrm{A}, \mathrm{B})$ lines and 2 restorers. The female parents were $\mathrm{AT} \times 624$ and ARhodesian sudangrass; the latter was developed from PI 156549 ( $S$. arundinaceum) and Combine Kafir 60 (CK-60) by Craigmiles in Georgia (3). Males were Common and Greenleaf sudangrass from now on referred to as Common and Greenleaf. Single crosses were made as $\mathrm{A} \times \mathrm{R}, \mathrm{A} \times \mathrm{B}$ and three-way crosses as $(\mathrm{A} \times \mathrm{B}) \times \mathrm{R}$ and $(\mathrm{A} \times \mathrm{B}) \times \mathrm{B}$. In some cases crosses among Common sudangrass and the sterile lines resulted in sterile crosses. These instead were used in various combinations for the development of three-way hybrids. Sets of five single crosses, five three-way hybrids and DeKalb hybrid SX-17 were tested at the Isabela experiment farm of MITA, ARS-SEA-USDA, in northwestern Puerto Rico. The farm is situated $128 \mathrm{~m}$ above sea level, and ambient temperatures range from $18^{\circ}$ to $31^{\circ} \mathrm{C}$. The soil is a Coto clay (Oxisol) with a pH of about 5.8 (15). The 10 hybrids and DeKalb SX-17 were machine planted on July 26, 
1979 , with a population density of about 100,000 plants/ha. Immediately after planting, propazine ${ }^{3}$ [2-chloro-4-6-bis-(isopropylamino)-s-triazine], was applied to all plots at 2 to $3 \mathrm{~kg}$ a.i./ha.

The experimental design was randomized complete blocks with four replications. Plots consisted of two rows spaced $101 \mathrm{~cm}$ apart and $6 \mathrm{~m}$ in length. Sampling area was $5 \mathrm{~m}^{2}$. The first cutting was at 60 days after planting; subsequent cuttings were made approximately every 52 days thereafter. The experiment was discontinued after the 4 th harvest. At planting, and after each cutting, a 15-5-10 fertilizer, equivalent to about $83 \mathrm{~kg} \mathrm{~N} / \mathrm{ha}$, was applied to all plots. Overhead irrigation was applied whenever necessary.

Before each cutting, plant height from the ground to the midpoint of the last leaf and number of tillers and leaf area were measured from 8 plants/plot chosen at random. Leaf area was determined by removing the second leaf from the top of the whorl, following the relationship maximum length $\times$ maximum width $\times 0.747 \times$ number of leaves $/$ plant based on the procedure developed by Stickler et al. (17). Green forage $(\mathrm{GF})$ and dry forage (DF) yields were calculated for each harvest. Samples were analyzed for dry matter and crude protein (CP) contents and HCN$\mathrm{p}$ at the MITA laboratories.

Leaf tissue was analyzed for $\mathrm{HCN}-\mathrm{p}$ with the spectrophotometric method described by Gorz et al. (5) with modifications in sample preparation. The third leaf from the distal end of the plant was sampled prior to each cutting, according to the suggestion of Benson et al. (1). Samples were obtained at random over the length of the blade, excluding the midrib with an ordinary hole puncher. Fifteen discs $6 \mathrm{~mm}$ in diameter were obtained from each treatment and placed in tared $10 \mathrm{ml}$ vials, and sealed. The sample was weighed and $5 \mathrm{ml}$ of distilled water added to each vial. Samples were then autoclaved for $60 \mathrm{~min}$ at $37^{\circ} \mathrm{C}$ to achieve hydrolysis and extraction of dhurrin. After autoclaving, the vials were cooled and $1 \mathrm{ml}$ of $0.1 \mathrm{~N} \mathrm{NaOH}$ was added. Absorbance values were then determined at $330 \mathrm{~nm}$, adjusting dilutions to register an absorbance in the range of 0.2 to 0.5 .

To convert the absorbance readings to $\mathrm{HCN}$ - $\mathrm{p}$ values in $\mathrm{p} / \mathrm{m}$, the following equation was used:

$$
p / m H C N=\frac{\left(A_{330}\right)(D F)(V E)(27.03)}{(\text { fr } w t)(27.9)}
$$

\footnotetext{
${ }^{3}$ Trade names in this publication are used only to provide specific information. Mention of a trade name does not constitute a warranty of equipment or materials by the Agricultural Experiment Station of the University of Puerto Rico, nor is this mention a statement of preference over other equipment or materials.
} 
where

$\mathrm{A}_{330}$ is the absorbance of the base-diluted sample at $330 \mathrm{~nm}$,

DF is the dilution factor if the sample had to be diluted,

$\mathrm{VE}$ is the volume $(\mathrm{ml})$ of distilled water used to extract the tissue, 27.03 is the formula weight of $\mathrm{HCN}(\mu \mathrm{g} / \mu$ mole), fr wt is the fresh weight (g) of the extracted tissue, and 27.9 is the extinction coefficient (ml/ $\mathrm{mole}$ ) at $330 \mathrm{~nm}$ of $\mathrm{p}-\mathrm{HB}$ in $0.1 \mathrm{~N} \mathrm{NaOH}$ solution.

The method is nondestructive and does not involve enzymatic hydrolysis of dhurrin. The HCN-p values calculated in this way are on a fresh weight basis.

TABLE 1.-Means and coefficient of variation (C.V.) in yields of green forage, dry forage, and crude protein; crude protein content; and height, leaf area, number of tillers, leaf/stem ratio and hydrocyanic acid potential in five single crosses, five threeway forage-sorghums and DeKalb hybrid SX-17 across four harvests at Isabela, Puerto Rico

\begin{tabular}{lrrrr}
\hline \multirow{2}{*}{ Characteristic } & \multicolumn{3}{c}{ Mean and coefficient of variation (C.V.) at each harvest } \\
\cline { 2 - 5 } & Harvest 1 & Harvest 2 & Harvest 3 & Harvest 4 \\
\hline Green forage yield (kg/ha) & 24,189 & 30,668 & 17,429 & 18,625 \\
C.V. (\%) & 8.67 & 9.33 & 11.96 & 14.66 \\
Dry forage yield (kg/ha) & 3,544 & 4,482 & 2,571 & 2,828 \\
C.V. (\%) & 9.31 & 9.23 & 12.48 & 15.37 \\
Crude protein (\%) & 14.12 & 11.29 & 12.18 & 12.40 \\
C.V. (\%) & 10.75 & 8.95 & 10.02 & 5.89 \\
Crude protein yield (kg/ha) & 500 & 504 & 313 & 350 \\
C.V. (\%) & 13.24 & 14.24 & 16.71 & 17.59 \\
Height (cm) & 215 & 259 & 181 & 184 \\
C.V. (\%) & 2.72 & 5.84 & 5.03 & 3.91 \\
Leaf area (cm $\left.{ }^{2}\right)$ & 5,552 & 6,855 & 3,775 & 4,016 \\
C.V. (\%) & 7.03 & 13.12 & 8.63 & 9.00 \\
Tillers, No. & 1.81 & 3.38 & 5.99 & 6.48 \\
C.V. (\%) & 14.53 & 14.58 & 13.38 & 13.40 \\
Leaf/stem ratio & 0.4246 & 0.4179 & 0.4260 & 0.4306 \\
C.V. $(\%)$ & 10.45 & 11.30 & 8.75 & 8.46 \\
HCN-p (p/m) & 268 & 280 & 245 & 260 \\
C.V. (\%) & 8.32 & 11.63 & 9.86 & 14.21 \\
\hline
\end{tabular}

Data were subjected to analysis of variance, orthogonal comparisons, and significant differences were identified with Duncan's multiple range test.

\section{RESULTS AND DISCUSSION}

Table 1 shows the means and coefficient of variation (C.V.) in GF, DF and CP yield; CP content, height, leaf area, leaf/stem ratio and HCN-p 
across the eleven hybrids at each harvest. The forage yields were usually highest at harvest 2. Yields of GF and DF in harvests 3 and 4 were very similar. In general, the highest plant height and leaf area were obtained. in harvest 2 , in agreement with the yield data.

Table 2 shows the mean GF, DF and CP yields, and the DM and CP contents of the eleven hybrids across the four harvests. The single cross hybrid of AT $\times 624 \times$ Common produced the highest GF yield, although this yield was not significantly different from those of $(\mathrm{AT} \times 624 \times$ BRhodesian $) \times$ Common and ARhodesian $\times$ Common. The GF yields ranged from 114,300 to 70,304 $\mathrm{kg} / \mathrm{ha}$, the three-way hybrid (ARhodesian $\times($ AT $\times 624 \times$ Greenleaf $)$ having the lowest value.

The single cross hybrid of AT $\times 624 \times$ Common produced the highest DF yield with $17,304 \mathrm{~kg} / \mathrm{ha}$, although this value was not significantly different from those of $(\mathrm{AT} \times 624 \times$ BRhodesian $) \times$ Common and $($ AT $\times 624 \times$ BRhodesian $) \times$ Greenleaf. The DF yields of the top producing hybrids are excellent, comparing well with those of some of the best perennial tropical grasses. At Isabela, Sotomayor-Ríos et al. (13) studied the effect of harvest intervals on 10 forage grasses. At the 30-day interval, the best yielder, Transvala digitgrass (Digitaria decumbens Stent), produced about $29,000 \mathrm{~kg} / \mathrm{ha} /$ year, whereas in the present study AT $\times 624$ $\times$ Common sudangrass produced almost $60 \%$ of that yield in only 217 days. Its daily DF yield was about $80 \mathrm{~kg} \cdot \mathrm{ha}^{-1}$.

The three-way hybrid (AT $\times 624 \times$ BRhodesian) $\times$ Greenleaf had the highest DM content (16.77\%), which was significantly superior to the remaining hybrids. The three-way hybrid (AT $\times 624 \times$ Common) $\times$ BT $\times 624$ exhibited the lowest DM content. Crude protein contents ranged from 13.06 to $11.68 \%$ and no significant differences were observed among the 11 hybrids. Similar results were obtained by Sotomayor and Santiago (16) when nine sorghum hybrids were evaluated at Isabela. The CP yields of the 11 hybrids ranged from 2,004 to $1,360 \mathrm{~kg} / \mathrm{ha}$; the single cross hybrid of AT $\times 624 \times$ Common was highest. This yield was not significantly different from those of $(\mathrm{AT} \times 624 \times$ BRhodesian $) \times$ Common, ARhodesian $\times$ Common, AT $\times 624 \times$ Greenleaf and $(\mathrm{AT} \times 624 \times$ BRhodesian $) \times$ Greenleaf.

Table 3 shows the mean height, leaf area, number of tillers, leaf/stem ratio and HCN-p values of the eleven hybrids across the four harvests. The single cross hybrid AT $\times 624 \times$ Common was the tallest, although not significantly different from the remaining hybrids except $(\mathrm{AT} \times 624 \times$ Common) $\times \mathrm{BT} \times 624, \mathrm{AT} \times 624 \times$ BRhodesian, and ARhodesian $\times$ $(\mathrm{AT} \times 624 \times$ Greenleaf).

The three-way hybrid (AT $\times 624 \times$ BRhodesian) $\times$ Common and the single cross hybrids AT $\times 624 \times$ Common and AT $\times 624 \times$ Greenleaf had 
TABLE 2.-Mean yields of green, dry forage and crude protein; dry matter and crude protein contents in five single crosses and five three-way forage-sorghums and DeKalb hybrid SX-17 across four harvests at Isabela, Puerto Rico ${ }^{1}$

\begin{tabular}{|c|c|c|c|c|c|}
\hline Hybrid & $\begin{array}{l}\text { Green forage } \\
\text { yield }\end{array}$ & $\begin{array}{c}\text { Dry forage } \\
\text { yield }\end{array}$ & Dry matter & $\begin{array}{l}\text { Crude protein } \\
\text { yield }\end{array}$ & $\begin{array}{l}\text { Crude } \\
\text { protein }\end{array}$ \\
\hline & $\mathrm{kg} / \mathrm{ha}$ & $\mathrm{kg} / \mathrm{ha}$ & $\%$ & $k g / h a$ & $\%$ \\
\hline $\mathrm{AT} \times 624 \times$ Common & $114300 \mathrm{a}$ & $17303 \mathrm{a}$ & $15.13 \mathrm{bc}$ & $2044 \mathrm{a}$ & $11.81 \mathrm{a}$ \\
\hline$($ AT $\times 624 \times$ BRhodesian $) \times$ Common & $109200 \mathrm{ab}$ & $15377 \mathrm{ab}$ & $14.08 \mathrm{bc}$ & $1924 \mathrm{abc}$ & $12.51 \mathrm{a}$ \\
\hline ARhodesian $\times$ Common & $101300 \mathrm{abc}$ & $14662 \mathrm{bc}$ & $14.47 \mathrm{abcd}$ & 1834 abcd & $12.51 \mathrm{a}$ \\
\hline AT $\times 624 \times$ Greenleaf & 97972 bcd & $14730 \mathrm{bc}$ & $15.03 \mathrm{bc}$ & 1722 abcde & $11.68 \mathrm{a}$ \\
\hline$($ AT $\times 624 \times$ BRhodesian $) \times$ Greenleaf & 93348 cde & $15657 \mathrm{ab}$ & $16.77 \mathrm{a}$ & $1954 \mathrm{ab}$ & $12.47 \mathrm{a}$ \\
\hline DeKalb Hybrid SX-17 & 89400 cde & $12624 \mathrm{~cd}$ & $14.12 \mathrm{bc}$ & 1553 cde & $12.29 \mathrm{a}$ \\
\hline AT $\times 624 \times($ ARhodesian $\times$ Greenleaf $)$ & 84248 def & $12408 \mathrm{~d}$ & $14.72 \mathrm{bc}$ & 1620 bcde & $13.06 \mathrm{a}$ \\
\hline ARhodesian $\times$ BT $\times 624$ & 81248 ef & $11190 \mathrm{~d}$ & $14.65 \mathrm{bc}$ & 1503 de & $12.61 \mathrm{a}$ \\
\hline AT $\times 624 \times$ BRhodesian & 79824 ef & $11480 \mathrm{~d}$ & $14.38 \mathrm{bc}$ & $1389 \mathrm{e}$ & $12.10 \mathrm{a}$ \\
\hline$(\mathrm{AT} \times 624 \times$ Common $) \times \mathrm{BT} \times 624$ & $78272 \mathrm{f}$ & $10705 \mathrm{~d}$ & $13.67 \mathrm{c}$ & $1432 \mathrm{e}$ & $13.37 \mathrm{a}$ \\
\hline ARhodesian $\times($ AT $\times 624 \times$ Greenleaf $)$ & $70304 \mathrm{f}$ & $10823 \mathrm{~d}$ & $15.30 \mathrm{~b}$ & $1360 \mathrm{e}$ & $12.56 \mathrm{a}$ \\
\hline$\overline{\mathrm{X}}$ & 90856 & 13425 & 14.76 & 1667 & 12.45 \\
\hline$\overline{\mathrm{X}}$ Single Crosses & 94299 & 14016 & 14.73 & 1698 & 12.14 \\
\hline$\overline{\mathrm{X}}$ Three-way Hybrids & 87074 & 12994 & 1.4 .92 & 1658 & 12.79 \\
\hline C.V. $(\%)$ & 10.82 & 11.26 & 6.27 & 15.20 & 9.26 \\
\hline
\end{tabular}

'Data are means across four replicate plots and four harvests. In each column, means followed by one or more letters in common do not differ significantly $(\mathrm{P}=.05)$, according to Duncan's multiple range test. 
TABLE 3.-Mean height, leaf area, number of tillers, leaf/stem ratio and hydrocyanic acid potential (HCN-p) in five single crosses and five three-way forage-sorghums and DeKalb hybrid SX-17 across four harvests at Isabela, P.R. ${ }^{1}$

\begin{tabular}{|c|c|c|c|c|c|}
\hline Hybrid & Height & Leaf area & Tillers & $\begin{array}{l}\text { Leaf/stem } \\
\text { ratio }\end{array}$ & HCN-p \\
\hline & $\mathrm{cm}$ & $\mathrm{cm}^{2}$ & No. & & $p / m$ \\
\hline$($ AT $\times 624 \times$ BRhodesian $) \times$ Common & 221 a & 7096 a & $4.73 \mathrm{abc}$ & $0.3360 \mathrm{efg}$ & $269 \mathrm{~cd}$ \\
\hline AT $\times 624 \times$ Common & $220 \mathrm{a}$ & $6737 \mathrm{a}$ & $4.60 \mathrm{abc}$ & $0.5393 \mathrm{~b}$ & 253 de \\
\hline AT $\times 624 \times$ Greenleaf & $220 \mathrm{a}$ & $6647 \mathrm{a}$ & $5.06 \mathrm{ab}$ & $0.5074 \mathrm{bc}$ & 340 a \\
\hline ARhodesian $\times$ Common & 218 a & $5261 \mathrm{~b}$ & $5.37 \mathrm{a}$ & $0.3802 \mathrm{de}$ & $320 \mathrm{ab}$ \\
\hline DeKalb Hybrid SX-17 & $215 \mathrm{ab}$ & $5166 \mathrm{~b}$ & $4.78 \mathrm{abc}$ & $0.4893 \mathrm{c}$ & $223 \mathrm{e}$ \\
\hline AT $\times 624 \times($ ARhodesian $\times$ Greenleaf $)$ & $212 \mathrm{ab}$ & $3109 \mathrm{e}$ & $5.54 \mathrm{a}$ & 0.3588 def & $219 \mathrm{e}$ \\
\hline$($ AT $\times 624 \times$ BRhodesian $) \times$ Greenleaf & $209 a b$ & $3978 \mathrm{~d}$ & $4.07 \mathrm{bcd}$ & $0.4034 \mathrm{~d}$ & $208 \mathrm{e}$ \\
\hline ARhodesian $\times$ BT $\times 624$ & $206 a b$ & $4854 \mathrm{bc}$ & $4.25 \mathrm{bcd}$ & 0.3717 de & $287 \mathrm{bcd}$ \\
\hline$(\mathrm{AT} \times 624 \times$ Common $) \times \mathrm{BT} \times 624$ & $202 \mathrm{~b}$ & $5593 \mathrm{~b}$ & $2.96 \mathrm{e}$ & $0.6913 \mathrm{a}$ & 247 de \\
\hline AT $\times 624 \times$ BRhodesian & $200 \mathrm{~b}$ & $4141 \mathrm{~cd}$ & 3.39 de & $0.3022 \mathrm{fg}$ & $224 \mathrm{e}$ \\
\hline ARhodesian $\times($ AT $\times 624 \times$ Greenleaf $)$ & $180 \mathrm{c}$ & $2875 \mathrm{e}$ & 3.82 cde & $0.2927 \mathrm{~g}$ & $307 \mathrm{abc}$ \\
\hline$\overline{\mathrm{X}}$ & 209 & 5041 & 4.42 & 0.4247 & 263 \\
\hline$\overline{\mathrm{X}}$ Single Crosses & 213 & 5528 & 4.53 & 0.4201 & 285 \\
\hline$\overline{\mathrm{X}}$ Three-way Hybrids & 205 & 4530 & 4.22 & 0.4164 & 250 \\
\hline C.V. $(\%)$ & 4.75 & 10.82 & 14.80 & 9.79 & 11.24 \\
\hline
\end{tabular}

${ }^{1}$ Data are means across four replicate plots and four harvests. In each columns, means followed by one or more letters in common do not differ significantly $(\mathrm{P}=.05)$, according to Duncan's multiple range test. 
the greatest leaf areas. Their values were significantly different from those of the remaining hybrids including DeKalb hybrid SX-17, which had about $37 \%$ less leaf area than the top hybrid, (AT $\times 624 \times$ BRhodesian) $\times$ Common. These results correspond to those of Liang et al. (8), who utilized the same procedure of Stickler et al. (17). Leaf area, along with plant height and number of tillers/plant, is an additional characteristic of importance influencing yield.

Three-way hybrid AT $\times 624 \times($ ARhodesian $\times$ Greenleaf) and single cross hybrid ARhodesian $\times$ Common had the highest number of tillers, although not significantly superior to most of the remaining hybrids. The coefficient of variation associated with number of tillers was large in this experiment and may explain the nonsignificant difference.

A high leaf/stem ratio indicates good forage quality. Sorghum genotypes having a larger proportion of leaves are more nutritious and will produce better hay than those with a low ratio. The three-way hybrid $($ AT $\times 624 \times$ Common) $\times$ BT $\times 624$ had the highest leaf/stem ratio (0.6913), significantly different from the remaining hybrids. The single cross hybrids, AT $\times 624 \times$ Common and AT $\times 624 \times$ Greenleaf, were the 2 nd and 3 rd best in terms of their leaf/stem ratios. These two hybrids were also excellent DF producers.

The potential HCN content of all the hybrids studied exceeded the "threshold of danger" of $200 \mathrm{p} / \mathrm{m}$ (7) at each harvest. The three-way hybrid $($ AT $\times 624 \times$ BRhodesian) $\times$ Greenleaf exhibited the lowest HCN content, while AT $\times 624 \times$ Greenleaf had the highest $(340 \mathrm{p} / \mathrm{m})$. The value cited is an approximation, representing the concentration of $\mathrm{HCN}$ at which it may become toxic to ruminant animals $(7,9)$.

Wolf and Washko (19) studied the distribution and concentration of HCN-p in several parts of a sorghum-sudangrass hybrid at three growth stages: 50-, 120-, and $155 \mathrm{~cm}$ height. Leaf blade minus midrib was high in $\mathrm{HCN}$ at all growth stages. Midrib, sheath, and stem portions decreased in HCN concentration with maturity. These authors attributed the decrease of $\mathrm{HCN}$ potential of the entire plant with age to the proportional increase in weight of the low-HCN parts. Our best producing hybrids, even those having $\mathrm{HCN}$ values exceeding the "threshold of danger" of $200 \mathrm{p} / \mathrm{m}$ in the leaves, can be recommended for green-chop feeding of animals, where the entire plant is consumed. According to the findings of Wolf and Washko (19), the animals fed green chop will be consuming a high proportion of low-HCN plant parts such as the stem, sheath and leaf midrib.

The present results could be of value in the selection of low-HCN cultivars; however, extensive research is needed to determine the "threshold of danger" applicable to the tropics.

Table 4 shows the statistical significance of the orthogonal comparisons 
TABLE 4.-Statistical significance (F values) or orthogonal comparisons for 11 hybrids (five single crosses versus five three-way hybrids and five single crosses and five three-way hybrids versus DeKalb hybrid SX-17) across four harvests at Isabela, P.R.

\begin{tabular}{|c|c|c|c|c|c|c|c|c|}
\hline Comparison & $\begin{array}{l}\text { Green } \\
\text { forage } \\
\text { yield }\end{array}$ & $\begin{array}{l}\text { Dry } \\
\text { forage } \\
\text { yield }\end{array}$ & $\begin{array}{l}\text { Crude } \\
\text { protein } \\
\text { yield }\end{array}$ & Height & Leaf area & $\begin{array}{l}\text { No. of } \\
\text { tillers }\end{array}$ & $\begin{array}{c}\text { Leaf/stem } \\
\text { ratio }\end{array}$ & HCN-p \\
\hline $\begin{array}{l}\text { Single cross versus three-way } \\
\text { hybrids }\end{array}$ & $104.40^{* * 1}$ & $73.13^{* *}$ & $4.09^{* 2}$ & $110.00^{* *}$ & $538.44^{* *}$ & $35.71^{* *}$ & 1.11 & $219.19^{* *}$ \\
\hline $\begin{array}{l}\text { Single cross and three-way } \\
\text { hybrids versus DeKalb hy- } \\
\text { brid SX-17 }\end{array}$ & 2.65 & $19.73^{* *}$ & $14.24^{* *}$ & $25.50^{* *}$ & 3.73 & $21.80^{* *}$ & $17.29 * *$ & $129.97^{* *}$ \\
\hline
\end{tabular}

${ }^{1}$ (p 0.01).
${ }^{2}$ (p 0.05). 
and means for the 11 hybrids (single cross versus three-way hybrids and single cross + three-way hybrids versus DeKalb hybrid SX-17). On the average, single crosses were superior to three-way hybrids in terms of GF, DF and CP yields, height, leaf area, and number of tillers. The threeway hybrids averaged higher than the single crosses in HCN content. The single cross and three-way hybrids were superior to DeKalb hybrid SX-17 in terms of DF and CP yields. DeKalb hybrid SC-17 exceeded the average combination of single cross hybrids and three-way hybrids in terms of plant height, leaf area, and HCN content.

The results indicate that these genotypes offer an excellent opportunity to farmers, interested in the utilization of forage sorghum hybrids under irrigation in Puerto Rico. The high DF yields and rapid regrowth of these hybrids, plus the possible availability of seed, could be decisive factors in more extensive utilization of forage sorghums in the beef and dairy industries in Puerto Rico.

\section{RESUMEN}

Cinco híbridos sencillos, cinco híbridos triples y el híbrido comercial DeKalb SX-17 se evaluaron en términos de forraje verde (GF), materia seca (DM), proteína bruta (CP), altura, área foliar, número de vástagos, razón hoja-tallo y potencial de ácido prúsico ( $\mathrm{HCN}-\mathrm{p})$ durante 217 días en Isabela, Puerto Rico. Se llevaron a cabo 4 cortes, el primero a los 60 días y los siguientes cada 52 días, aproximadamente. Se utilizaron las yerbas sudán "Greenleaf" y "Common" como progenitores masculinos y las líneas androesterériles "AT $\times 624$ " y "ARhodesian sudangrass" como progenitores femeninos. En adición, se utilizaron las líneas "BT $\times 624$ " y "BRhodesian sudangrass" como mantenedoras de las respectivas líneas $\mathrm{A}$. El segundo corte registró la mayor producción de forraje seco (DF) y el menor contenido de CP. Al combinar los cuatro cortes, el híbrido sencillo AT $\times 624 \times$ Common, el híbrido triple (AT $\times 624$ $\times$ BRhodesian) $\times$ Common y el híbrido sencillo ARhodesian $\times$ Common fueron los mayores productores en términos de DF, resultando significativamente superiores al híbrido comercial DeKalb SX-17. La producción de DF del híbrido sencillo AT $\times 624 \times$ Common $(17,303 \mathrm{~kg} / \mathrm{ha}$ en 217 días) fue superior en 11 y 13\%, respectivamente, con relación a los híbridos que resultaron segundo y tercero en producción de DF. A base de las comparaciones ortogonales, los híbridos sencillos fueron en promedio superiores a los híbridos triples en producción y otras características estudiadas. Los híbridos triples registraron en promedio menos HCN-p (250 ppm) al compararse con los híbridos sencillos (285 ppm). Estos valores son ligeramente superiores al nivel de 200 ppm, nivel sobre el cual el HCN-p puede ser tóxico para el ganado. Los resultados indican, que los híbridos que registraron los rendimientos más altos tienen magníficas potencialidades para usarse como forrajeras en la Isla. 
La producción de DF del híbrido sencillo AT×624 × Common de 17,303 $\mathrm{kg} / \mathrm{ha}$ en un período de 217 días o de $80 \mathrm{~kg} \cdot \mathrm{ha}^{-1} \mathrm{dia}^{-1}$ con una CP de $12 \%$ es excelente, especialmente cuando la yerba se puede cortar en los trópicos a intervalos cortos.

\section{LITERATURE CITED}

1. Benson, J. A., Gray, E. and Fribourg, H. A., 1969. Relation of hydrocyanic acid potential of leaf samples to that of whole plants of sorghum, Agron. J. 61: 223-24.

2. Burgex, A. W. and Hittle, C. N., 1967. Yield, protein, nitrate and prussic acid content of sudangrass, sudangrass hybrids, and pearl millets harvested at two cutting frequencies and two stubble heights, Agron. J. 59: 259-62.

3. Craigmiles, J. P., 1961. The development, maintenance, and utilization of cytoplasmic male sterility for hybrid sudangrass seed production, Crop Sci. 1: 150-52.

4. Gorashi, A. M., Drolsom, P. N., and School, J. M., 1980. Effect of stage of growth, temperature, and $\mathrm{N}$ and $\mathrm{P}$ levels on the hydrocyanic acid potential of sorghums in the field and growth room, Crop Sci. 20: 45-7.

5. Gorz, H. J., Haag, W. L., Specht, J. E., and Haskins, F. A., 1977. Assay of p-hydroxybenzaldehyde as a measure of hydrocyanic acid potential in sorghums, Crop Sci. 17: 578-82.

6. Hunt, B. J. and Taylor, A. O., 1975. Hydrogen cyanide production by field grown sorghums, N. Z. J. Exp. Agric. 4: 191-94.

7. Kingsbury, J. M., 1964. Poisonous plants of the United States and Canada, Prentice Hall, Inc., Englewood Cliffs, N. J.

8. Liang, G. H., Chu, C. C., Reddi, N. S., Lin, S. S., and Dayton, A. D., 1973. Leaf blade areas of grain sorghum varieties and hybrids, Agron. J. 65: 456-59.

9. McBee, G. C. and Miller, F. R., 1980. Hydrocyanic acid potential in several sorghum breeding lines as affected by nitrogen fertilization and variable harvests, Crop Sci. 20 : 232-34.

10. Morales, A., Annual Report on development of improved high yielding sorghum cultivars, contract No. AID/ta-c1087, June 1, 1975-May 31, 1976, Agric. Exp. Stn. Univ. P. R., Mayagüez, P.R.

11. Patanothai, A. and Atkins, R. E., 1974. Genetic effects for mean yield responses to environments in three-way single-cross hybrids of grain sorghum, Crop Sci. 14: 48489.

12. Ross, W. M., 1969. Performance of three-way sorghum hybrids, 24th Ann. CornSorghum Res. Conf. Proc. Am. Seed Trade Assoc. p. 129-34.

13. Sotomayor-Ríos, A., Juliá, F. and Arroyo-Aguilú, J. A., 1974. Effects of harvest intervals on the yield and composition of 10 forage grasses, J. Agric. Univ. P.R. 58: 448-55.

14. - and Telek, L., 1977. Forage yield and protein content of Millo Blanco (Sorghum bicolor) and two $\mathrm{F}_{1}$ hybrids, J. Agric. Univ. P.R. 61 (3): 300-04.

15. - and Lugo-López, M. A., 1978. Nitrogen fertilization of sorghum in an Oxisol in northwestern Puerto Rico, J. Agric. Univ., P.R. 62 (4): 380-88.

16. and Santiago, A., 1981. Performance of three-sudan grasses and six forage sorghums when crossed to ARhodesian sudangrass, J. Agric. Univ. P.R. 65 (2): 142-46.

17. Stickler, F. C., Wearden, S., and Pauli, A. W., 1961. Leaf Area Determination in Grain Sorghum, Agron. J. 53: 187-88.

18. Vázquez, R., Eschenwald-Hess, A., and Martínez-Luciano, M. J., 1966. Response of native white sorghum to irrigation under different nitrogen-fertility levels and seeding rate in Lajas Valley, P.R., J. Agric. Univ. P.R. 50: 73-112.

19. Wolf, D. D. and Washko, W. W., 1967. Distribution and concentration of HCN in a sorghum-sudangrass hybrid, Agron. J. 59: 381-82. 